\title{
URINARY RADIO-IODINE EXCRETION IN THE MALNOURISHED INFANT
}

\author{
BY \\ R. D. MONTGOMERY* \\ From the Medical Research Council Tropical Metabolism Research Unit, \\ University College of the West Indies, Jamaica
}

(RECEIVED FOR PUBLICATION APRIL 10, 1962)

Although it has been suggested on the basis of animal experiments that endocrine imbalance may play a part in some of the clinical features of malnutrition (Gillman and Gilbert, 1958), there is very little supporting evidence of this. With regard to the thyroid gland, there have been inconstant findings of histological atrophy and of decreased $\mathrm{I}^{\mathbf{1 3 1}}$ uptake in undernourished adults (Zubirán and Gómez-Mont, 1953). In undernourished infants Stirling (1962) has recently shown that the appearance of the thyroid gland is compatible with normal function. S. Frenk (1961, personal communication) found initially normal levels of serum proteinbound iodine (P.B.I.) and butanol-extractable iodide (B.E.I.) in malnourished infants, with a rise during recovery which was greatest in the B.E.I. fraction and appeared to be progressive over a period of 60 days. The nature of endocrine changes during the recovery of these infants is of particular interest in view of the fact that the basal oxygen consumption shows a dramatic rise, sometimes more than twofold, to a plateau level during the early weeks of rehabilitation (Montgomery, 1962).

This paper reports a study of urinary $\mathbf{I}^{131}$ excretion and its relation to basal oxygen uptake in Jamaican infants suffering from, and recovering from, severe protein malnutrition.

\section{Iodine Metabolism in Normal Infants}

The use of $I^{131}$ in normal children has usually been confined to direct measurement of uptake over the gland (Lowrey, Beierwalters, Lampe and Gomberg, 1949; Silverman and Wilkins, 1953; Friedman, 1955; Van Middlesworth, 1954; Martmer, Corrigan, Charbeneau and Sosin, 1956; Sheline, Koulischer and Pickering, 1957). Quimby and McCune (1947) and Reilly and Bayer (1952) also reported on the normal range of $\mathbf{I}^{131}$ excretion, and

\footnotetext{
* Present address: Department of Experimental Medicine, University of Cambridge.
}

serum protein-bound $\mathrm{I}^{131}$ activity in childhood was studied by Reilly, Scott, Winters and Helwig (1955). Non-radioactive P.B.I. and B.E.I. were measured in the serum of newborn babies by Danowski, Johnston, Price, McKelvy, Stevenson and McCluskey (1951) and by Man, Pickering, Walker and Cooke (1952).

From these studies it may be concluded that throughout early life the uptake and urinary excretion of radio-iodine fall within the range of normal in adults and do not vary significantly with age. There is disagreement as to whether iodine uptake is increased in the immediate neonatal period (Van Middlesworth, 1954; Martmer et al., 1956), but the finding of an unusually high range of P.B.I. in infancy may be due to increased thyroxinebinding capacity of the serum rather than to hyperthyroidism (Reilly et al., 1955; Dowling, Freinkel and Ingbar, 1956).

\section{Radiation Hazards}

Since the observation by Duffy and Fitzgerald (1950) of an association between thyroid carcinoma in childhood and previous thymus irradiation, several reports have suggested an increased susceptibility of the thyroid gland to radiation hazards in early life (Clark, 1955; Winship and Chase, 1955; Simpson and Hempelmann, 1957). This suspicion is not allayed by more recent negative evidence (Uhlmann, 1956; Snegireff, 1959), although the danger may have been exaggerated. With regard to $I^{131}$, its carcinogenic potential in the thyroid gland has been shown experimentally, provided that the production of thyroid-stimulating hormone is artificially increased by administration of thioureas (Goldberg and Chaikoff, 1952; Doniach, 1953). $I^{131}$ is potentially more carcinogenic than $\mathrm{X}$-ray irradiation, and this may well be due to its irregular distribution in the gland.

These considerations seem to contraindicate the further use of $\mathrm{I}^{131}$ in infants by the techniques which 
have been quoted above. The dose range of all these investigations (except in newborn babies) was from 5 to $50 \mu \mathrm{c}$., and exceeded $1 \mu \mathrm{c}$. $/ \mathrm{kg}$. body weight.

In the present study a dosage was adopted of $0.01 \mu \mathrm{c} . / \mathrm{kg}$. The calculated mean radiation dose to the gland was of the order of $0.25 \mathrm{rad}$. This small dosage precluded the estimation of thyroid gland uptake or serum $I^{131}$ activity.

\section{Material and Methods}

Twenty-four $\mathrm{I}^{131}$ tests were made on 12 Jamaican infants suffering from protein malnutrition, most of whom showed the typical clinical picture of marasmic kwashiorkor (Jelliffe, Bras and Stuart, 1954; Hansen, 1961). Their ages ranged from 4 to 21 months. At the time of admission all were more than $40 \%$ underweight for their age by American standards (Nelson, 1954).

Five cases were tested within 10 days of admission, and two others at a later stage but before the onset of weight gain. The remainder of the estimations were done at various stages of recovery. Three infants each had three tests, at intervals of two to nine weeks.

All cases were subjected to serial estimations of basal metabolic rate during the same period.

Radio-iodine Excretion. $I^{131}$ in a dose of $0.01 \mu \mathrm{c}$. $/ \mathrm{kg}$. body weight was administered orally and total urine collections were made for the periods 0 to eight hours, eight to 24 hours and 24 to 48 hours (in four cases only 24-hour collections were obtained). Aliquots of $80 \mathrm{ml}$. urine were acidified to approximately $p \mathrm{H} 3$, and chloride and iodide were precipitated by an excess of saturated silver nitrate. The precipitate was transferred to standard tubes and centrifuged to give a final volume of precipitate not exceeding $3 \mathrm{ml}$. per tube. Radioactivity was then counted directly in a well-type scintillation crystal through an automatic scaler. As standards, $10 \%$ of the administered $\mathrm{I}^{181}$ dose was $(a)$ counted in $3 \mathrm{ml}$. water and (b) added to a control urine specimen and precipitated in the same way. Preliminary tests proved that there was no interference with the $\mathrm{I}^{131}$ count due to the precipitate-standards $(a)$ and (b) giving strictly comparable readings - and that the counts were constant for sample volumes ranging from 0.5 to $3 \mathrm{ml}$. The range of recovery of precipitated $\mathrm{I}^{131}$ was $94-108 \%$.
Basal Metabolic Rate. Basal oxygen consumption was measured volumetrically in a closed circuit system as previously described (Montgomery, 1962). The infants were tested at complete rest in the post-absorptive state in saturated air at a temperature of $29-31^{\circ} \mathrm{C}$. $\left(84-88^{\circ} \mathrm{F}\right.$.). Tests were run for 45-60 minutes and calculations were based on oxygen uptake during the last 20 minutes.

\section{Results}

Initial Phase. Tests on five infants soon after admission showed normal 24-hour and 48-hour $I^{131}$ excretion (Table 1). It is to be noted, however, that one of the 48-hour figures approached hypothyroid levels; and the ' $T$ index' (Fraser, Hobson, Arnott and Emery, 1953) suggested hypothyroidism in three cases. This is due to the relatively high excretion in the eight to 24-hour period.

The probable explanation of this is that infants were liable to complete the first eight-hour collection with a full bladder; as the total urine output at this stage was often low a considerable discrepancy is introduced (catheterization was not thought to be a justifiable procedure; the accuracy of total 24-hour and 48-hour excretion is not significantly affected). The figures therefore cannot be taken as evidence of hypothyroidism or of impaired renal function.

Phase of Recovery. During recovery $\mathrm{I}^{131}$ excretion decreased in four out of seven subjects, and the mean result of estimations in 11 recovering cases was noticeably lower than that of the initial estimations (Table 2). In only two infants, however, did the final excretion during recovery clearly fall short of the reported normal range (Fig. 1).

In several instances normal $\mathbf{I}^{131}$ excretion figures coincided with maximal weight gain and high oxygen consumption, notably in cases M.B., H.E., and D.D., in each of whom $\mathrm{I}^{131}$ excretion remained within normal limits in three successive tests while the B.M.R. rose to exceed 70 cals./kg./day (Table 3).

TABLE 1

URINARY RADIO-IODINE EXCRETION AND BASAL METABOLIC RATE OF MALNOURISHED INFANTS ON ADMISSION

\begin{tabular}{|c|c|c|c|c|c|c|}
\hline \multirow{2}{*}{ Case } & \multicolumn{4}{|c|}{ I131 Excretion ( $\%$ of dose) } & \multirow[b]{2}{*}{$\begin{array}{c}\text { T Index } \\
\text { (normal 2-15) }\end{array}$} & \multirow{2}{*}{$\begin{array}{l}\text { B.M.R. } \\
\text { (cals./kg./24 hours) } \\
\text { (normal 45-60) }\end{array}$} \\
\hline & $\begin{array}{l}0-8 \\
\text { Hours }\end{array}$ & $\begin{array}{l}\text { 8-24 } \\
\text { Hours }\end{array}$ & $\begin{array}{l}24-48 \\
\text { Hours }\end{array}$ & $\begin{array}{l}\text { Total } 48 \text { Hours } \\
\text { (normal 28-70) }\end{array}$ & & \\
\hline $\begin{array}{l}\text { D.D. } \\
\text { M.B. } \\
\text { C.G. } \\
\text { H.E. } \\
\text { M.P. }\end{array}$ & $\begin{array}{r}9 \\
17 \\
20 \\
16\end{array}$ & $\begin{array}{l}53 \\
41 \\
22 \\
19\end{array}$ & $\begin{array}{r}8 \\
7 \\
12 \\
3\end{array}$ & $\begin{array}{c}70 \\
65 \\
54 \\
38 \\
46 \\
(24 \mathrm{hrs})\end{array}$ & $\begin{array}{l}0 \cdot 5 \\
0 \cdot 6 \\
1 \cdot 7 \\
2 \cdot 2\end{array}$ & $\begin{array}{l}52 \\
55 \\
51 \\
52 \\
47\end{array}$ \\
\hline
\end{tabular}

* The $T$ Index of Fraser et al. $(1953)=\frac{(0-8 \text { hour excretion }) \times 100}{(8-24 \text { hour excretion }) \times(0-48 \text { hour excretion })}$ 


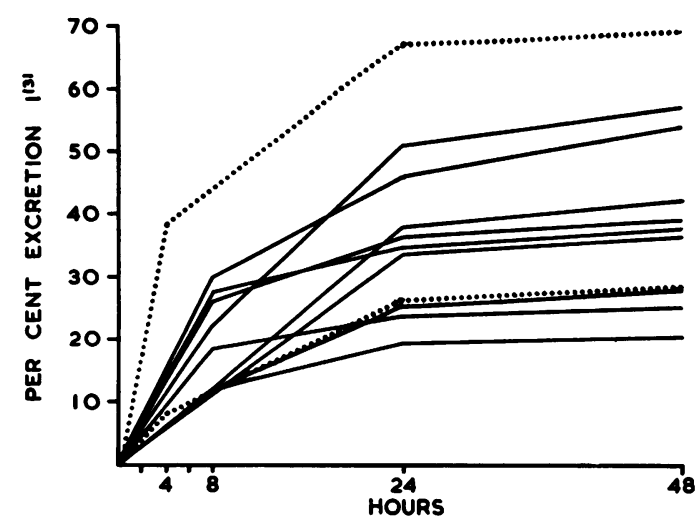

FiguRE.-Urinary radio-iodine excretion in nine infants recovering from severe malnutrition, 20 to 80 days after hospital admission. Excretion is expressed as a percentage of the administered dose. The dotted lines indicate the limits of normal excretion as observed by Reilly and Bayer (1952).

TABLE 2

24-HOUR URINARY RADIO-IODINE EXCRETION OF MALNOURISHED INFANTS BEFORE AND AFTER THE RISE IN OXYGEN UPTAKE

\begin{tabular}{c|c|c|c}
\hline Case & $\begin{array}{c}\text { Initial } \\
\text { I131 (\% of dose) }\end{array}$ & $\begin{array}{c}\text { Recovering } \\
\text { I131 (\% of dose) }\end{array}$ & $\begin{array}{c}\text { Peak B.M.R. } \\
\text { (cals./kg./24 hrs) }\end{array}$ \\
\hline C.G. & 42 & 51 & 60 \\
D.D. & 62 & 46 & 80 \\
D.G. & 37 & 41 & 78 \\
H.E. & 35 & 38 & 81 \\
R.B. & 51 & 38 & 72 \\
M.B. & 58 & 36 & 71 \\
E.G. & & 28 & 86 \\
T.S. & 46 & 27 & 90 \\
M.P. & & 25 & 112 \\
F.A. & & 25 & 79 \\
S.F. & 43 & 23 & 90 \\
L.C. & 47 & 19 & \\
\hline Mean & & 33 & \\
(Range) & $(35-62)$ & $(19-51)$ & \\
\hline
\end{tabular}

TABLE 3

SUCCESSIVE RADIO-IODINE EXCRETION TESTS IN THREE CASES, SHOWING LACK OF CORRELATION WITH B.M.R.

\begin{tabular}{|c|c|c|c|c|}
\hline Case & $\begin{array}{c}\text { Days } \\
\text { After } \\
\text { Admission }\end{array}$ & $\begin{array}{c}\text { Oxygen } \\
\text { Uptake } \\
\text { (ml./min.) }\end{array}$ & $\begin{array}{l}\text { B.M.R. } \\
\text { (cals./kg./ } \\
\text { day) }\end{array}$ & $\begin{array}{c}\text { I131 Excretion } \\
(0-48 \text { hrs }) \\
\% \text { of Dose }\end{array}$ \\
\hline M.B. & $\begin{array}{l}10 \\
24 \\
40\end{array}$ & $\begin{array}{l}49 \cdot 0 \\
71 \cdot 9 \\
78 \cdot 5\end{array}$ & $\begin{array}{l}55 \\
71 \\
69\end{array}$ & $\begin{array}{l}68 \\
34 \\
37\end{array}$ \\
\hline H.E. & $\begin{array}{r}2 \\
32 \\
48\end{array}$ & $\begin{array}{l}44 \cdot 1 \\
74 \cdot 8 \\
87 \cdot 6\end{array}$ & $\begin{array}{l}52 \\
74 \\
81\end{array}$ & $\begin{array}{l}38 \\
62 \\
41\end{array}$ \\
\hline D.D. & $\begin{array}{r}1 \\
17 \\
80\end{array}$ & $\begin{array}{l}34 \cdot 2 \\
59 \cdot 5 \\
54 \cdot 8\end{array}$ & $\begin{array}{l}52 \\
80 \\
62\end{array}$ & $\begin{array}{l}70 \\
54 \\
49\end{array}$ \\
\hline
\end{tabular}

\section{Comment}

The results suggest that in the initial malnourished state the thyroid activity of these infants is within normal limits. This agrees with the normal histological appearance of the gland (Stirling, 1962) and is perhaps also in keeping with the finding that basal oxygen consumption is approximately normal in terms of body solid mass (Montgomery, 1962).

During recovery there tends to be a slight increase in thyroid activity, as judged by $\mathbf{I}^{131}$ excretion. It seems, however, that this increase neither initiates clinical recovery nor plays a major role in the immense immediate increase in oxygen consumption. It appears to be merely one item in the general pattern of accelerated growth.

\section{Summary}

Radio-iodine urinary excretion tests were carried out in 12 infants suffering from protein malnutrition. A technique of iodide precipitation was used, involving a dosage of $0.01 \mu \mathrm{c}$. $\mathrm{I}^{131} / \mathrm{kg}$. Changes in basal metabolic rate were observed in the same infants.

In the initial phase of hospital admission radioiodine excretion was essentially normal. During recovery some cases showed a decrease in excretion. This decrease, however, was unrelated to dramatic increases in oxygen uptake and body weight and tended to lag behind them.

It is concluded that thyroid action may facilitate, but in no way initiates, the accelerated respiratory activity during recovery.

The author is indebted to Professor J. C. Waterlow, Director of this Unit, for his advice and practical assistance in this study.

\section{REFERENCES}

Clark, D. E. (1955). Association of irradiation with cancer of the thyroid in children and adolescents. J. Amer. med. Ass., 159, 1007.

Danowski, T. S., Johnston, S. Y., Price, W. C., McKelvy, M., Stevenson, S. S. and McCluskey, E. R. (1951). Protein-bound iodine in infants from birth to one year of age. Pediatrics, 7, 240.

Doniach, I. (1953). The effect of radioactive iodine alone and in combination with methylthiouracil upon tumour production in the rat's thyroid gland. Brit. J. Cancer, 7, 181.

Dowling, J. T., Freinkel, N. and Ingbar, S. H. (1956). Thyroxinebinding by sera of pregnant women, newborn infants, and women with spontaneous abortion. J. clin. Invest., 35, 1263.

Duffy, B. J., Jr. and Fitzgerald, P. J. (1950). Thyroid cancer in childhood and adolescence; a report on twenty-eight cases. Cancer $(N . Y), 3,1018$.

Fraser, R., Hobson, Q. J. G., Arnott, D. G. and Emery, E. W. (1953) The urinary excretion of radioiodine as a clinical test of thyroid function. Ouart. J. Med., 22, 99.

Friedman, A. (1955). Radioiodine uptake in children with mongolism. Pediatrics, 16, 55.

Gillman, J. and Gilbert, C. (1958). Fatty liver of endocrine origin, with special reference to fatty liver of malnourished African infants. Brit. med. J., 1, 57.

Goldberg, R. C. and Chaikoff, I. L. (1952). Induction of thyroid cancer in the rat by radioactive iodine. A.M.A. Arch. Path., $53,22$.

Hansen, J. D. L. (1961). Protein malnutrition and its prevention and treatment with special reference to kwashiorkor and marasmus. In Recent Advances in Human Nutrition, ed. J. F. Brock, p. 267. Churchill, London. 
Jelliffe, D. B., Bras, G, and Stuart, K. L. (1954), Kwashiorkor and marasmus in Jamaican infants. $W$. Indian med. J., 3, 43.

Lowrey, G. H., Beierwalters, W. H., Lampe, I. and Gomberg, H. J• (1949). Radioiodine uptake curve in humans. II. Studies in children. Pediatrics, 4, 627.

Man, E. B., Pickering, D. E., Walker, J. and Cooke, R. E. (1952). Butanol-extractable iodine in the serum of infants. ibid., 9, 32 .

Martmer, E. E., Corrigan, K. E., Charbeneau, H. P. and Sosin, A. (1956). A study of the uptake of iodine (1131) by the thyroid of premature infants. ibid., 17, 503 .

Montgomery, R. D. (1962). Changes in the basal metabolic rate of the malnourished infant and their relation to body composition. J. clin. Invest. In the press.

Nelson, W. E. (1954). Text Book of Pediatrics, 6th ed., p. 54. Saunders, Philadelphia.

Quimby, E. H. and McCune, D. J. (1947). Uptake of radioactive iodine by the normal and disordered thyroid gland in children. Radiology, 49, 201.

Reilly, W. A. and Bayer, D. I. (1952). The value of the measurements of thyroid uptake and urinary excretion of $\mathrm{I}^{131}$ in assessing thyroid function of normal and congenitally hypothyroid children. J. Pediat., 40, 714.
Scott, K. G., Winters, R. W. and Helwig, H. L. (1955). Anionic resin measurement of protein-bound $\mathbf{I}^{131}$ in euthyroid children. A.M.A. Amer. J. Dis. Child., 89, 572.

Sheline, G. E., Koulischer, N. and Pickering, D. (1957). Thyroidal accumulation of radioiodine in children. A.M.A.J. Dis. Child., 93, 391.

Silverman, S. H. and Wilkins, L. (1953). Radioiodine uptake in the study of different types of hypothyroidism in childhood. Pediatrics, 12, 288.

Simpson, C. L. and Hempelmann, L. H. (1957). The association of tumours and roentgen-ray treatment of the thorax in infancy. Cancer $(N . Y), 10,42$.

Snegireff, L. S. (1959). The elusiveness of neoplasia following roentgen therapy for thymic enlargement in childhood. Radiology, 72, 508.

Stirling, G. A. (1962). The thyroid in malnutrition. Arch. Dis. Childh 37.99

Uhlmann, E. M. (1956). Cancer of the thyroid and irradiation. J. Amer. med. Ass., 161, 504.

Van Middlesworth, L. (1954). Radioactive iodine uptake of normal newborn infants. A.M.A. Amer. J. Dis. Child., 88, 439.

Winship, T. and Chase, W. W. (1955). Thyroid carcinoma in children. Surg. Gynec. Obstet., 101, 217.

Zubirán. S. and Gómez-Mont, F. (1953). Endocrine disturbances in chronic human malnutrition. Vitam. and Horm., 11, 97. 